\title{
Penyesuaian Diri di Sekolah pada Anak yang Mengalami Selective Mutism
}

\author{
Nurul Inayah Zainuddin ${ }^{1}$, Andi Alfiah ${ }^{2}$ \\ Fakultas Psikologi, Universitas Airlangga \\ Fakultas Psikologi, Universitas Negeri Makassar \\ znurulinayah@gmail.com
}

\begin{abstract}
ABSTRAK
Penelitian ini bertujuan untuk memahami penyesuaian diri di sekolah pada anak yang mengalami selective mutism dengan usia 12 tahun yang saat ini duduk di bangku sekolah dasar. Penelitian ini menggunakan metode penelitian kualitatif dengan pendekatan fenomenoligi untuk mengetahui gambaran psikologis anak yang memiliki gangguan selective mutism, dengan jumlah responden 7 orang antara lain 1 responden, dan 6 informan. Teknik pengumpulan data yang digunakan yaitu wawancara menggunakan guide interview dan observasi. Berdasarkan hasil penelitian yang dilakukan dapat disimpulkan bahwa pengalaman responden yang beragam dan penuh tekanan akan memengaruhi penyesuaian diri anak di sekolahnya, terkhususnya anak yang terbukti mengalami selective mutism yang seketika memberikan penilaian mengenai lingkungan sekolah sehingga responden mengambil sikap di lingkungan sosial berbeda dengan lingkungan rumahnya.
\end{abstract}

Keywords: Selective mutism, Anak, Penyesuaian diri di sekolah.

\section{School Adjustment in Children with Selective Mutism}

\begin{abstract}
This study aims to understand the school adjustment for children with selective mutism 12 years old and a student in elementary school. This study uses a qualitative research approach to determine the image phenomenology psychological disorders of children who have selective mutism, this study have 7 persons as subjects include one respondent, and 6 informants. Data collection techniques used were interviews using an interview guide and observation. Based on the research, results can be concluded that the subjects experience a diverse and full of pressure will affect the child's school adjustment, children with proven especially with selective mutism which instantly provides an assessment of the school environment so that subjects taking a different attitude in the social environment to the home environment.
\end{abstract}

Keywords: Selective mutism, Children, School adjustment.

\section{PENDAHULUAN}

Masa kanak-kanak adalah masa dengan rentang usia antara 2 tahun sampai pada usia 14 tahun (Hurlock, 1980). Perkembangan individu pada masa kanak-kanak mencakup perkembangan fisik, kognitif, emosi, maupun psikososial (Jahja, 2011). Hurlock (1980) mengemukakan bahwa individu pada masa kanak-kanak (anak) memiliki keinginan untuk mengetahui keadaan lingkungannya, mekanisme yang ada dalam lingkungan, perasaan, dan menjadi bagian dari lingkungan. Namun, tidak semua anak mampu beradaptasi dengan lingkungannya, sehingga masa perkembangannya di periode ini terganggu.

Salah satu gangguan yang terjadi pada anak yang ditandai tidak inginnya anak berbicara dan 
berinteraksi dengan orang dilingkungannya disebut sebagai selective mutism (Sluckin dan Smith, 2015). Sluckin dan Smith (2015) melanjutkan bahwa anak dengan selective mutism berbicara lancar dengan kawan-kawan karibnya, tetapi tidak berbicara di lingkungan asing yang mereka tidak kenal, bahkan kadang-kadang di lingkungan yang berhubungan dengan mereka. Selective mutism pertama kali diidentifikasi pada tahun 1877 oleh Adolf Kussmaul, yang menyebut kondisi tersebut sebagai aphasia voluntaria, dan kemudian disebut sebagai elective mutism, dengan pengertian bahwa anak-anak yang memilih untuk tidak berbicara dalam suatu kondisi (Krysanski, 2003).

Smyth (2012) mengemukakan bahwa selective mutism (SM) adalah gangguan kecemasan pada anak yang ditandai anak bisu dalam lingkungan tertentu tapi mampu berbahasa dengan santai di rumahnya. Anak dengan SM tidak berbicara demi melindungi diri dari kecemasan yang parah. SM ditandai dengan keadaan dimana anak terus menerus mengalami kegagalan untuk berbicara (Cohan dkk, 2006). Anak yang mengalami selective mutism kasusnya jarang sekali ditemukan terjadi (Sluckin dan Smith, 2015).

Sloan (2007) menyatakan bahwa kasus SM adalah kasus yang jarang terjadi, dan hanya terjadi pada kurang dari 1\% kasus klinis. Statistik menunjukkan bahwa di Indonesia, SM diderita oleh 6 dari 1000 anak ditandai dengan serangan kecemasan yang berlebihan. Jumlah tersebut hampir sama dengan jumlah anak penderita autisme (Sidauruk, 2015). Hal tersebut menunjukkan kasus SM juga terjadi di Indonesia, tak terkecuali di Kota Makassar, Sulawesi Selatan.

Y (12) adalah salah satu anak di Kota Makassar, telah didiagnosa SM sejak usia kanak-kanak awal. Usia 12 tahun merupakan usia anak pada jenjang pendidikan di sekolah dasar. Dimana pada usia tersebut anak telah mampu mengembangkan keterampilan berpikir dan bertindak dan pengaruh sosial yang lebih kompleks. Daya konsentrasi anak tumbuh pada kelas tinggi pada jenjang sekolah dasar. Mereka dapat meluangkan lebih banyak waktu untuk tugas-tugas pilihan mereka, dan seringkali mereka dengan senang hati menyelesaikannya. Tahap ini juga termasuk tumbuhnya tindakan mandiri, kerjasama dengan kelompok dan bertindak menurut cara-cara yang dapat diterima lingkungan mereka (Hurlock, 1980). Berdasarkan wawancara, diketahui bahwa orangtua Y belum mengetahui gangguan yang dialami anaknya, hingga akhirnya ke dokter anak, dan diketahuilah bahwa Y mengalami SM. Ketika menginjak usia 3 tahun, Y mengalami penekanan dari pihak pengajar. Penekanan itulah yang kemudian menyebabkan kecemasan pada anak di lingkungan sekolah, karena menurut Smyth (2012) tempat umum dan sekolah adalah tempat dimana anak dengan SM tidak mau berbicara.

Lingkungan sekolah menjadi dunia baru bagi anak selain di lingkungan rumah. Anak ketika memasuki lingkungan sekolah tentunya membutuhkan penyesuaian diri, tak terkecuali pada anak dengan SM. Penyesuaian diri menurut Bauserman (2002) adalah keadaan individu dalam mengatasi suatu masalah dan kondisi yang dihadapi di lingkungannya. Semiun (2006) sendiri mendefinisikan 
penyesuaian diri sebagai proses yang mencakup mental dan tingkah laku individu. Hal tersebut menyebabkan individu berusaha menanggulangi kebutuhan, tegangan-tegangan, rasa frustrasifrustrasi, dan konflik serta menyelaraskan tuntutan-tuntutan lingkungan.

Pada periode kehidupan anak, anak akan mempelajari dasar-dasar mereka berperilaku pada lingkungan sekitarnya sebagai persiapan menjalani kehidupan sosial yang membutuhkan penyesuaian diri (Hurlock, 1980). Hurlock (1980) melanjutkan bahwa awal anak masuk ke sekolah dibutuhkan penyesuaian diri. Anak dengan SM tentunya sulit menyesuaikan diri dengan lingkungan sekolahnya dikarenakan tidak maunya anak berbicara selain di lingkungan rumah.

Cunningham dkk, (2004) mengemukakan bahwa anak-anak dengan SM memiliki kekurangan yang signifikan dalam keterampilan sosial, yang ditunjukkan dengan lebih memilihnya anak untuk membisu. Kumpulainen dkk (1998) melaporkan bahwa anak dengan SM ditemukan 2\% dari seluruh populasi. Kebanyakan kasus menunjukkan anak telah didiagnosis SM lebih dari satu tahun. 58\% anakanak menolak untuk berbicara dengan guru, seperlimanya bahkan tidak berbicara pada siapa pun di sekolah. Anak dengan SM dicirikan sebagai anak yang serius, tidak hiperaktif, dan pemalu, sehingga anak kesulitan untuk menyesuaikan diri di sekolahnya.

Responden dalam penelitian ini yaitu Y (12) yang telah didiagnosis SM memilih tidak berbicara dengan teman di sekolahnya namun tetap berkomunikasi dengan orang-orang di rumahnya. Namun, sedikit demi sedikit Y sudah mulai berkomunikasi dan menjalin hubungan dengan orang-orang di sekolahnya meskipun hanya sebahagian kecil saja, itupun interaksinya sangat minim. Oleh karena itu, peneliti akan meneliti mengenai penyeuaian diri di sekolah pada anak dengan SM yaitu responden Y.

\section{METODE}

Metode penelitian dalam penelitian ini menggunakan metode penelitian kualitatif. Peneltian kualitatif adalah penelitian yang dilakukan untuk memahami makna tentang fenomena tertentu berdasarkan pandangan-pandangan dari responden penelitian (Creswell, 2007). Jenis pendekatan penelitian yang digunakan dalam penelitian ini adalah pendekatan fenomenologi. Creswell (2007) mengungkapkan bahwa pendekatan penelitian fenomenologi dilakukan untuk mengungkap jati diri responden berdasarkan hidup yang dijalaninyab yang berfungsi untuk mengetahui pengalaman responden mengenai masalah atau isu yang ingin diteliti.

Istilah yang digunakan dalam penelitian ini adalah Selective mutism dan Penyesuaian diri di sekolah.

1. Selective mutism adalah gangguan yang dialami anak dimana anak memilih tidak berbicara pada suatu situasi tertentu, namun tetap berbicara di situasi lainnya. 
2. Penyesuaian diri di sekolah adalah proses mental dan tingkah laku individu dimana individu menanggulangi kebutuhan untuk menyelaraskan tuntutan-tuntutan lingkungan.

Krejcie dan Morgan (1970) mengemukakan bahwa dibutuhkan metode yang efisien untuk menentukan ukuran sampel dalam penelitian. Responden yang terlibat dalam penelitian ini dipilih menggunakan teknik purposive sampling. Kriteria responden dalam penelitian ini antara lain:

1. Anak dengan selective mutism (hasil pemeriksaan tenaga professional) yang dalam proses penyembuhan.

2. Berusia antara 4 hingga 14 tahun.

3. Individu lain yang terkait dengan anak dengan selective mutism selaku responden, seperti orang tua, atau saudara, ataupun guru-guru sekolah.

Teknik pengumpulan data yang digunakan dalam penelitian ini adalah teknik pengambilan data melalui proses wawancara dan observasi. Metode wawancara yang digunakan merupakan wawancara yang bersifat tidak terstruktur dengan tetap mengacu pada guide yang berkaitan dengan masalah penelitian. Observasi yang digunakan dalam penelitian ini adalah teknik observasi dengan bentuk semi-terstruktur. Adapun hasil wawancara sebahagian diambil dari penelitian yang dilakukan peneliti sebelumnya (Alfiah, 2015).

Teknik analisis data yang dilakukan adalah metode pendekatan interaktif. Creswell (2010) mengemukakan bahwa metode pendekatan interaktif dilakukan dengan beragam tahap yang saling berhubungan. Adapun tahap-tahapnya adalah sebagai berikut:

1. Mengolah dan mempersiapkan data untuk dianalisis.

2. Membaca keseluruhan data.

3. Melakukan coding (memberikan tanda pada informasi dengan melabeli menggunakan istilah khusus).

4. Membagi hasil informasi yang telah dibuat dengan cara coding ke dalam beberapa tema dan deskripsi khusus.

5. Menyajikan kembali hasil temuan penelitian berupa tema-tema dan deskripsi-deskripsi ke dalam bentuk narasi.

6. Menginterpretasi data dengan mencoba memaknai setiap data yang diperoleh.

Verifikasi keabsahan data merupakan tahapan yang dilakukan sebagai antisipasi apabila terjadi perubahan dan segala sesuatu yang bersifat sementara pada saat proses pengambilan data (Sugiyono, 2008). Verifikasi data yang dilakukan dengan responden adalah dengan menunjukkan data yang telah dibentuk dalam pengkodean dengan tema dan deskripsi data yang diperoleh. Responden selanjutnya diminta untuk mengecek hasil yang diperoleh peneliti. 


\section{HASIL DAN PEMBAHASAN}

Berdasarkan hasil observasi dan wawancara yang telah dilakukan kepada enam orang informan dan satu orang responden penelitian yang mengalami selective mutism diperoleh hasil yaitu, ciri-ciri anak yang mengalami selective mutism (SM) sering kali muncul pada usia sekolah dengan beragam pengalaman trauma. Responden Y memperlihatkan ciri anak SM khususnya di lingkungan sekolah dengan tidak ingin berbicara secara lisan dengan orang-orang di lingkungan sekolah, dan lebih memilih berkomunikasi melalui tulisan pada setiap orang yang menanyainya, serta responden $\mathrm{Y}$ meminimalisir komunikasi lebih dulu kepada orang lain, kecuali menurut responden $\mathrm{Y}$ orang tersebut membuat dirinya nyaman untuk berkomunikasi meski dengan tulisan.

Dampak trauma yang terjadi pada responden Y dimulai awal mulai pendidikan usia 4 tahun tepatnya area lingkungan sekolah si anak. Responden $\mathrm{Y}$ yang menurut keenam informan termasuk anak yang pintar, hingga suatu hari diawal sekolahnya kurang mendapatkan perlakuan positif dari hasil tugas yang dikerjakannya, sementara guru yang memberikan perlakuan saat itu mengambil sikap dengan merobek hasil tugas yang diselesaikan responden Y. Hal ini yang membuat responden Y memperlihatkan beberapa perubahan khususnya saat di sekolah dengan kurang aktif berkomunikasi dan memilih berdiam di kelas dibandingkan bergabung dengan teman-teman.

Selain itu, trauma yang dialami oleh responden Y terlihat memengaruhi perubahan penyesuaian diri di sekolah yang saat ini di jenjang sekolah dasar secara akademik, sosial, dan emosi. Secara akademik, responden Y memilih diam saat diminta berdiri di depan kelas atau sekolah dalam suatu kegiatan. Oleh karenannya, kebanyakan tugas yang mengharuskan responden Y untuk berpresentasi di depan kelas dengan cara modifikasi hasil tugas yaitu membuat video di rumah dan hasil video diri responden Y di setiap pelajaran yang dipresentasikan di kelas. Sosialisasi di lingkungan sekolah saja responden Y memilih seorang atau dua teman/guru yang akan lebih didekati untuk bermain seperti menonton atau membuat tugas bersama. Emosi yang diperlihatkan responden Y lebih agresif memberi respon untuk perlakuan yang kurang disukai, seperti memukul atau mendorong pintu. Sementara jika responden $\mathrm{Y}$, cenderung menutup mulut saat tertawa agar tidak terdengar suara tawa ataupun memperlihatkan gigi.

Anak cenderung memilih diam pada kasus anak SM disebabkan oleh kecemasan pada suatu keadaan. Kasus responden Y memperlihatkan terjadi konflik di masa lalu yang membuat responden Y cemas pada lingkungan dan suasana seperti kejadian sebelumnya dan berakhir pada trauma. Kecemasan inilah yang akhirnya memengaruhi faktor penghambat penyesuaian diri responden $\mathrm{Y}$ khususnya pada lingkungan sekolah yang sebelumnya di masa lalu responden Y mendapatkan perlakuan buruk di lingkungan sekolah dan akhirnya memengaruhi pula pada persepsi terhadap realitas 
meskipun telah berada di sekolah yang berbeda-beda.

Smyth (2012) mengemukakan bahwa SM adalah gangguan kecemasan pada anak yang ditandai anak bisu dalam lingkungan tertentu tapi mampu berbahasa dengan santai di rumahnya. Responden $\mathrm{Y}$ adalah anak yang periang saat berada di rumah dan aktif berbicara secara lisan pada seluruh anggota keluarganya di rumah, hanya saja setiba mendekati lingkungan sekolah, responden Y memilih diam (tidak berbicara) meskipun itu anggota keluarganya. Haber dan Runyon (Ningrum, 2013) mengemukakan bahwa terdapat lima aspek dalam penyesuaian diri, yaitu persepsi terhadap realitas, kemampuan mengatasi stres dan kecemasan, gambaran diri yang positif, kemampuan mengekspresikan emosi, dan memiliki hubungan interpersonal yang baik. Responden $\mathrm{Y}$ mampu memerlihatkan penyesuaian diri di sekolah yang baik jika berhasil pada kelima aspek penyesuaian diri, khususnya penilaian responden $\mathrm{Y}$ pada sekolah terdahulu yang membuatnya merasa cemas dapat dibedakan saat berada di sekolah yang baru.

Salah satu gangguan yang terjadi pada anak yang ditandai tidak inginnya anak berbicara dan berinteraksi dengan orang lain di lingkungannya disebut sebagai SM (Sluckin dan Smith, 2015). Responden $\mathrm{Y}$ awalnya sama sekali tidak ingin berbicara dengan orang lain, hingga intervensi dari pihak sekolah mengarahkan untuk berbicara melalui tulisan saja dan interaksi pun diawal terlihat senang di dalam kelas sendiri saat makan ataupun jam bermain sehingga responden Y membiarkan dirinya makan diakhir waktu setelah teman-teman di kelasnya usai makan dan kelas kosong dikarenakan anak-anak di kelas bermain di luar kelas. Schneiders (1960) mengungkapkan individu disebut mempunyai penyesuaian diri yang baik bila mempunyai keterampilan sosial dan kemampuan untuk berhubungan dengan orang lain baik, dengan orang sebaya maupun dengan orang yang belum dikenalnya.

\section{SIMPULAN}

Pengalaman responden yang beragam dan penuh tekanan akan memengaruhi penyesuaian diri anak di sekolahnya, terkhususnya anak yang terbukti mengalami selective mutism yang seketika memberikan penilaian mengenai lingkungan sekolah sehingga responden mengambil sikap di lingkungan sosial berbeda dengan lingkungan rumahnya. Namun, intervensi yang dilakukan oleh pihak sekolah kepada responden mempu mengarahkan responden untuk berbicara, walaupun awalnya hanya dengan tulisan saja, sehingga sedikit demi sedikit responden akan mampu menyesuaikan diri di sekolahnya. 


\section{DAFTAR PUSTAKA}

Alfiah, A. (2015). Penyesuaian sosial pada anak yang mengalami selective mutism. Universitas Negeri Makassar. Bauserman, R. (2002). Child adjustment in joint-custody versus sole-custody arrangements: A metaanalytic review. Family Psychology, 16(1), 91-102.

Cohan, S. L., Chavira, D. a., \& Stein, M. B. (2006). Practitioner review: Psychosocial interventions for children with selective mutism: A critical evaluation of the literature from 1990-2005. Journal of Child Psychology and Psychiatry and Allied Disciplines, 47, 1085-1097. http://doi.org/10.1111/j.14697610.2006.01662.x

Creswell, J. . (2010). Research design: Pendekatan kualitatif, kuantitatif, dan mixed (3rd ed.). Yogyakarta: Pustaka Pelajar.

Creswell, J. W. (2007). Qualitative enquiry \& research design, choosing among five approaches (Vol. 2, p. 395). London: SAGE Publications. http://doi.org/10.1016/j.aenj.2008.02.005

Cunningham, C. E., McHolm, A., Boyle, M. H., \& Patel, S. (2004). Behavioral and emotional adjustment, family functioning, academic performance, and social relationships in children with selective mutism. Journal of Child Psychology and Psychiatry and Allied Disciplines, 45(8), 1363-1372. http://doi.org/10.1111/j.1469-7610.2004.00327.x

Hurlock, E. B. (1980). Psikologi Perkembangan: Suatu pendekatan sepanjang rentan kehidupan. Jakarta: Penerbit Erlangga.

Jahja, Y. (2011). Psikologi perkembangan. Jakarta: Kencana.

Krejcie, R. V, \& Morgan, D. W. (1970). Determining Sample Size for Research Activities. Educational and Psychological Measurement, 30, 607-610.

Krysanski, V. L. (2003). A brief review of selective mutism literature. The Journal of Psychology, 137(1), 29-40. http://doi.org/10.1080/00223980309600597

Kumpulainen, K., Räsänen, E., Raaska, H., \& Somppi, V. (1998). Selective mutism among secondgraders in elementary school. European Child and Adolescent Psychiatry, 7, 24-29. http://doi.org/10.1007/s007870050041

Ningrum, P. R. (2013). Perceraian orang tua dan penyesuaian diri remaja. Psikologi, 1(1), 69-79.

Schneiders, A. A. (1960). Personal adjustment and mental health. Illinois: Holt, Reinhart and Winston Inc.

Semiun, Y. (2006). Kesehatan mental 1: Pandangan umum mengenai penyesuaian diri dan kesehatan mental serta teori-teori yang terkait. Yogyakarta: Kansius.

Sidauruk, A. (2015). Terapi Gangguan Selective Mutism SM. Retrieved July 01, 2016, from http://www.ayahbunda.co.id/balita-gizi-kesehatan/terapi-gangguan-selective-mutism-sm-

Sloan, T. L. (2007). Family therapy with selectively mute children: A case study. Journal of Marital and Family Therapy, 33(1), 94-105. http://doi.org/10.1111/j.1752-0606.2007.00008.x

Sluckin, A., \& Smith, B. R. (2015). Tacking selective mutism: Guide for professionals and parents. Statewide Agricultural Land Use Baseline 2015 (Vol. 1). London: Jessica Kingsley Publishers. http://doi.org/10.1017/CBO9781107415324.004

Smyth, R. (2012). Helping children and youth with selective mutism : Information for parents and caregivers. Ottawa: Cheo.

Sugiyono. (2008). Memahami penelitian kualitatif. Bandung: Alfabeta. 